\title{
Insulin secretory actions of extracts of Asparagus racemosus root in perfused pancreas, isolated islets and clonal pancreatic $\beta$-cells
}

\author{
J M A Hannan ${ }^{1}$, Lamin Marenah, Liaquat Ali ${ }^{1}$, Begum Rokeya ${ }^{1}$, Peter R Flatt and Yasser H Abdel-Wahab \\ Diabetes Research Group, School of Biomedical Sciences, University of Ulster, Coleraine, BT52 1SA Northern Ireland, UK \\ ${ }^{1}$ Biomedical Research Group, Department of Pharmacology, BIRDEM, Dhaka 1000, Bangladesh \\ (Requests for offprints should be addressed to Y H Abdel-Wahab; Email: y.abdel-wahab@ulster.ac.uk)
}

\begin{abstract}
Asparagus racemosus root has previously been reported to reduce blood glucose in rats and rabbits. In the present study, the effects of the ethanol extract and five partition fractions of the root of $A$. racemosus were evaluated on insulin secretion together with exploration of their mechanisms of action. The ethanol extract and each of the hexane, chloroform and ethyl acetate partition fractions concentration-dependently stimulated insulin secretion in isolated perfused rat pancreas, isolated rat islet cells and clonal $\beta$-cells. The stimulatory effects of the ethanol extract, hexane, chloroform and ethyl acetate partition fractions were potentiated by glucose, 3-isobutyl-1-methyl
\end{abstract}

xanthine IBMX, tolbutamide and depolarizing concentration of $\mathrm{KCl}$. Inhibition of $A$. racemosus-induced insulin release was observed with diazoxide and verapamil. Ethanol extract and five fractions increased intracellular $\mathrm{Ca}^{2+}$, consistent with the observed abolition of insulin secretory effects under $\mathrm{Ca}^{2+}$-free conditions. These findings reveal that constituents of $A$. racemosus root extracts have wide-ranging stimulatory effects on physiological insulinotropic pathways. Future work assessing the use of this plant as a source of active components may provide new opportunities for diabetes therapy.

Journal of Endocrinology (2007) 192, 159-168

\section{Introduction}

Diabetes mellitus (DM) is a major cause of disability and hospitalization that presents a significant burden on societies worldwide (Roglic et al. 2005, Booth et al. 2006). By the year 2010 , the total number of people with DM is projected to reach more than 300 million. In Asia and Africa, there are limitations on presently available therapeutic options for diabetes, such as oral hypoglycaemic agents and insulin (Prout 1974, Holman \& Turner 1991, Kameswara Rao et al. 1997). In such circumstances, herbal medicines for the treatment of diabetes become significant. Available literature reveals that more than 400 plant species have been claimed to have anti-hyperglycaemic activity (Mukherjee 1981, Oliver-Bever 1986, Atta-Ur-Rahman \& Zaman 1989, Ivorra et al. 1989, Rai 1995). The recent explosion in the area of herbal medicine has lead to a resurgence of nutritional, clinical and scientific interest in the potential of plant treatments for diabetes across the world (Swanston-Flatt et al. 1991a,b, Gray \& Flatt 1997).

Asparagus racemosus (Liliaceae) is a popular vegetable consumed in many parts of the world and grows naturally throughout India, Asia, Australia and Africa. It is commonly used for the treatment of diarrhoea, dysentery, rheumatism, nervous breakdown, and is thought to be an aphrodisiac (Nadkarni 1976, Chadha 1985). The root of the plant has also been claimed by traditional healers to possess antidiabetic properties.
Studies on the extracts of $A$. racemosus have revealed a wide range of biological activities. These include antimutagenic, antitumor, antifungal (Edenharder 1990, Shimoyamada et al. 1990, Shao et al. 1996), diuretic (Balansard \& Rayband 1987) and immunostimulatory effects (Thatte \& Dahanukar 1988, Rege et al. 1999, Dhuley 1997). A. racemosus has been considered to be a lactogogue in lactational inadequacy (Sharma et al. 1996) and useful to decrease post-operative adhesions (scars; Rege et al. 1999). The protective effects of $A$. racemosus against the myelosuppression with single and multiple doses of cyclophosphamide have also been demonstrated (Thatte \& Dahanukar 1988). Asparagus roots inhibited the growth of human leukaemia HL-60 cells (Shao et al. 1996) and more recently A. racemosus has been shown to exert antioxidant properties in rat liver mitochondrial membranes (Kamat et al. 2000).

The chemical constituents of $A$. racemosus have been studied to some extent. The compounds so far reported include flavonoids, oligosaccharides, amino acids, sulphur-containing acids and steroidal saponins (Shao et al. 1996). Various reports suggest that polysaccharides derived from the plant exhibit antioxidant as well as radioprotective properties (Gang et al. 1997, Liu et al. 1997a,b, Zeng et al. 1997). The polysaccharide kreskin also has been shown to have inhibitory effects on the oxidation of low density lipoprotein (LDL; Liu et al. 1997a,b). However, most studies evaluate mixtures of constituents and the fresh root juice of $A$. racemosus has been found to be effective in dyspepsia, being associated with anti-ulcerogenic activity (De et al. 1997, Sairam 
et al. 2003). It has been reported that asparagus decreases gastric emptying time (Dalvi et al. 1990). Other studies have shown that the methanolic extracts of asparagus root reduced intestinal propulsive movement, castor oil-induced diarrhoea and intestinal fluid accumulation (Rege et al. 1999, Nwafor et al. 2000).

As well as claims by traditional healers that the roots of $A$. racemosus have antidiabetic properties, studies have reported reduced blood glucose level in rats and rabbits (Akhtar \& Shah 1993, Rana et al. 1994). However, the mechanism of action has not yet been elucidated. In the present study, the effects of ethanol extract and five partition fractions of $A$. racemosus roots were evaluated on insulin secretion using the perfused rat pancreas, isolated rat islets and clonal $\beta$-cells.

\section{Materials and Methods}

\section{Plant materials and preparation of extract and fractions}

Dried roots of $A$. racemosus were purchased from the Ramkrishna Mission, Kolkata, India and botanically authenticated. Voucher specimens were deposited in the National Herbarium, Bangladesh. The roots were dried in an oven at $40{ }^{\circ} \mathrm{C}$ and ground into a fine powder. The powder $(2 \mathrm{~kg})$ was extracted with $80 \%$ ethanol (10 l) in a stainless steel extraction tank for approximately 4 days at room temperature by changing ethanol daily. The combined extract was filtered and evaporated to dryness using rotary evaporator. A membrane pump was used to evacuate the extract in order to remove the residual solvent. The extract was finally freeze-dried (330 g) using a Varian 801-model LY-3-TT freeze-dryer (USA). The dry sample was stored at $4{ }^{\circ} \mathrm{C}$ in a freezer. The ethanol extract $(414 \mathrm{~g})$ was subsequently partitioned between hexane $(0.51 \times 3)$ and water $(0.51)$. Hexane was separated and evaporated to dryness to get hexane-soluble material $(1.64 \mathrm{~g})$. The aqueous layer was further partitioned by chloroform $(0.51 \times 3)$, ethyl acetate $(0.51 \times 3)$ and 1-butanol $(0.51 \times 3)$. These were finally evaporated to dryness to get chloroform $(2 \cdot 9 \mathrm{~g})$, ethyl acetate $(1.9 \mathrm{~g})$ and 1-butanol $(59 \mathrm{~g})$ soluble materials. The residual aqueous part was condensed by rotary evaporator and finally freeze-dried $(342 \mathrm{~g})$. Figure 1 briefly outlines the preparation of ethanol extract and five partition fractions of dried roots of $A$. racemosus. Freeze-dried extract and fractions were subsequently reconstituted in KrebsRinger bicarbonate buffer prior to evaluation of the effects of $A$. racemosus on insulin release from perfused pancreas, isolated islets and clonal $\beta$-cell line (BRIN-BD11).

\section{Effects of A. racemosus on insulin secretion from perfused pancreas}

Long-Evans rats (180-250 g) were anesthetized with sodium pentobarbital solution $(50 \mathrm{mg} / \mathrm{kg}$, i.p.) and the pancreas was isolated and perfused at $37^{\circ} \mathrm{C}$ according to the method of Giroux et al. (1983). Extract and fractions of $A$. racemosus were dissolved in KRB buffer ( $\mathrm{pH} 7 \cdot 4$ ): $118 \mathrm{mM} \mathrm{NaCl}, 4 \mathrm{mM}$ $\mathrm{KCl}, 2.5 \mathrm{mM} \mathrm{CaCl}_{2}, 1.2 \mathrm{mM} \mathrm{MgSO}$, $1.2 \mathrm{mM} \mathrm{KH}_{2} \mathrm{PO}_{4}$,
$25 \mathrm{mM} \mathrm{NaHCO}, 1.25 \mathrm{~g} / 1 \mathrm{BSA}$ and $40 \mathrm{~g} / 1$ dextran T70) containing $2.8 \mathrm{mM}$ or $11.1 \mathrm{mM}$ D-glucose. The perfusate was continuously gassed with a mixture of $\mathrm{O}_{2}: \mathrm{CO}_{2}$ (95:50). After a 20-min equilibration period, the composition of the perfusate was changed as indicated in Fig. 1. Effluent samples were frozen and stored at $-20{ }^{\circ} \mathrm{C}$ for insulin assay.

Effects of A. racemosus on insulin secretion from isolated islets

Islets were isolated from pancreas of Long-Evans rats (180-250 g body weight (bw)) by collagenase digestion (Moskalewski 1969). Following pre-incubation for $40 \mathrm{~min}$ in KRB containing $3 \mathrm{mM}$ glucose, batches of $8-10$ islets were incubated for $1 \mathrm{~h}$ at $37^{\circ} \mathrm{C}$ in $400 \mu \mathrm{l}$ buffer containing either 3 or $11.1 \mathrm{mM}$ glucose and either extracts or fractions of A. racemosus as shown in Table 1 . Aliquots of supernatant were frozen and stored at $-20{ }^{\circ} \mathrm{C}$ for insulin assay.

Effects of A. racemosus on insulin secretion and intracellular $\mathrm{Ca}^{2+}$ from clonal $\beta$-cells

Clonal BRIN-BD11 cells were used to evaluate the mechanism of action of $A$. racemosus on insulin secretion and intracellular $\mathrm{Ca}^{2+}$. The origin and characteristics of this rodent cell line are described in detail elsewhere (McClenaghan et al. 1996). Cells were seeded in the multiwell plates at a concentration of $0 \cdot 15 \times$ $10^{6}$ and allowed to attach overnight. Following pre-incubation for $40 \mathrm{~min}$ in KRB supplemented with $1.1 \mathrm{mM}$ glucose, cells were incubated for $20 \mathrm{~min}$ at $37^{\circ} \mathrm{C}$ with KRB supplemented with glucose, plant extracts and other reagents as indicated in the figures. Aliquots were removed from each well and stored at $-20^{\circ} \mathrm{C}$ for insulin assay. In another series of experiments, the effects of $A$. racemosus on intracellular $\mathrm{Ca}^{2+}\left(\left[\mathrm{Ca}^{2+}\right]_{\mathrm{i}}\right)$ were determined using monolayers of BRIN-BD11 cells seeded in 96-well black-walled, clear bottom microplates (Greiner). Cells were washed with KRB and loaded with FLEXslation calcium assay reagents (Molecular Devices, Sunnyvale, CA, USA), for 10-min incubation at $37^{\circ} \mathrm{C}$ (Miguel et al. 2004). Fluorometric data during subsequent exposure to extract and test agents indicated in Fig. 5 were acquired at a wavelength of $525 \mathrm{~nm}$ using the FLEXstation (Molecular Devices).

\section{Statistical analysis}

For perfusion and islet studies, insulin was measured by ELISA using kits supplied by Crystal Chem. Inc (Downers Grove, IL, USA). In studies using BRIN-BD11 cells, insulin was measured by RIA (Flatt \& Bailey 1981). The protein content of islets was determined using detergent compatible/ protein kit supplied by Bio-Rad. Cell viability was evaluated by modified neutral red assay (Hunt et al. 1987). Results are presented as mean \pm s.D. for a given number of observations $(n)$. Data from each set of observations were compared using unpaired Student's unpaired $t$-test and Mann-Whitney U-test where appropriate (SPSS for Windows). One-way ANOVA was performed and comparisons with the control group made 


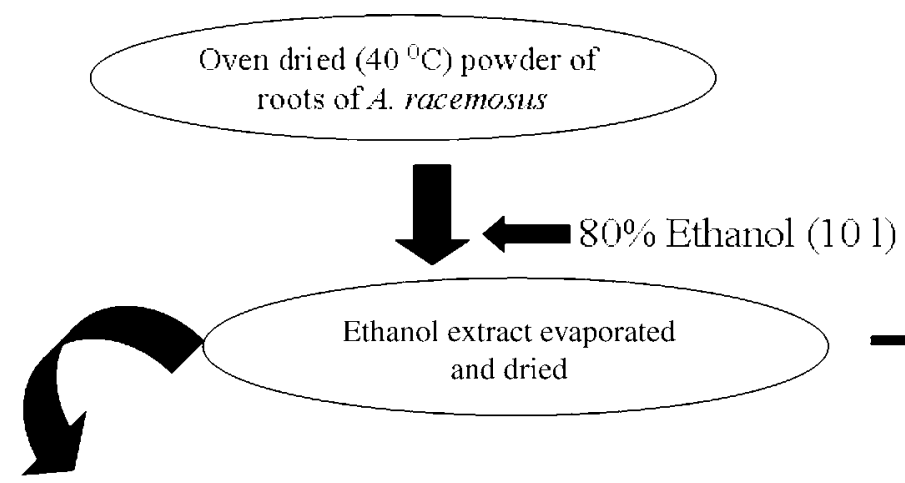

Dried ethanol extract partitioned between Hexane $(0.51 \times 3)+$ water $(0.51 \times 1)$

Aqueous layer was further partitioned by chloroform $(0.51 \times 3)$, ethyl acetate

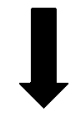

Hexane fraction $(051 \times 3)$ and 1 -butanol $(0.5 \times 31)$

Non-aqueous layer

Dried and evaporated

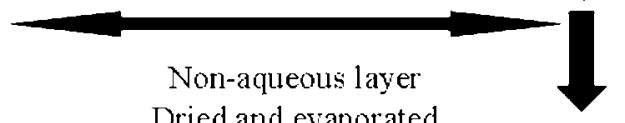

Chloroform fraction

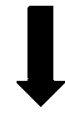

Butanol fraction

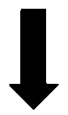

Ethyl acetate fraction

Aqueous layer dried and evaporated Aqueous fraction

Figure 1 Preparation of ethanol extract and five partition fractions (heaxane, ethyl acetate, butanol, chloroform and aqueous fractions) of dried roots of $A$. racemosus.

using Dunnett's test to preserve an overall error rate of $5 \%$. Differences were considered significant if $P<0 \cdot 05$.

\section{Results}

Effects of A. racemosus on insulin secretion from perfused pancreas

Ethanol extract caused a significant $(P<0 \cdot 001)$ increase in insulin release during 10 -min perfusion, with a 21 -fold increase above basal $(0 \cdot 06 \pm 0 \cdot 01 \mathrm{ng} / \mathrm{ml}$ at $2 \cdot 8 \mathrm{mM}$ glucose (basal) vs $1 \cdot 27 \pm 0 \cdot 09 \mathrm{ng} / \mathrm{ml}$ with ethanol extract; Fig. 2A, Table 2). Subsequent exposure for $5 \mathrm{~min}$ to $11.1 \mathrm{mM}$ glucose caused steep elevation in insulin release. When extract was reintroduced at $11.1 \mathrm{mM}$ glucose, there was a further enhancement of insulin release $(P<0 \cdot 05)$. As shown in Fig. $2 \mathrm{~B}$ and Table 2, perfusion with hexane, chloroform and ethyl acetate fractions evoked a significant increase in insulin release in an almost similar pattern, with a peak increase above basal of 36-, 18- and 28-fold respectively $(2 \cdot 8 \mathrm{mM}$ glucose (basal) $0 \cdot 05 \pm 0 \cdot 01 \mathrm{ng} / \mathrm{ml}$, hexane $1 \cdot 2 \pm 0 \cdot 2 \mathrm{ng} / \mathrm{ml}$, chloroform $0 \cdot 9 \pm 0 \cdot 1 \mathrm{ng} / \mathrm{ml}$, ethyl acetate

Table 1 Effects of ethanol extract and five partition fractions of $A$. racemosus on insulin secretion from isolated rat islets. Data are presented as median (range), $n=8$

Insulin ( $\mathrm{ng} / \mathrm{mg}$ islet protein)

\section{Grams obtained from $1 \mathrm{~kg}$ starting materials $(\mathrm{g} / \mathrm{kg})$}

\section{Group}

Control $(n=6)$

$80 \%$ ethanol extract $(n=6) \quad 165$

Ethyl acetate fraction $(n=7) \quad 0 \cdot 8$

Butanol fraction $(n=6) \quad 30$

Aqueous fraction $(n=6) \quad 137$

Hexane fraction $(n=6) \quad 0 \cdot 7$

Chloroform fraction $(n=6) \quad 1 \cdot 2$

\begin{tabular}{|c|c|}
\hline Glucose: $3 \mathrm{mM}$ & Glucose: $11 \mathrm{mM}$ \\
\hline $2 \cdot 99(2 \cdot 65-4 \cdot 27)$ & $5 \cdot 41(4 \cdot 91-9 \cdot 27)^{\dagger}$ \\
\hline $5 \cdot 01(2 \cdot 91-7 \cdot 16)^{*}$ & $6 \cdot 67(5 \cdot 38-9 \cdot 11)^{*}$ \\
\hline $6 \cdot 16(5 \cdot 01-8 \cdot 50)^{*}$ & $5 \cdot 51(7 \cdot 25-10 \cdot 37)^{*}$ \\
\hline $3 \cdot 83(2 \cdot 51-4 \cdot 71)^{*}$ & $5 \cdot 91(4 \cdot 49-7 \cdot 61)^{*}$ \\
\hline $3 \cdot 54(2 \cdot 05-4 \cdot 56)$ & $5 \cdot 79(4 \cdot 99-8 \cdot 78)$ \\
\hline $5 \cdot 69(4 \cdot 74-6 \cdot 54)^{*}$ & $5 \cdot 98(4 \cdot 17-7 \cdot 88) *$ \\
\hline $4 \cdot 98(3 \cdot 01-6 \cdot 76)^{*}$ & $6 \cdot 37(5 \cdot 15-8 \cdot 57)^{*}$ \\
\hline
\end{tabular}

Isolated rat islets were incubated for $60 \mathrm{~min}$ with ethanol extract and five partition fractions of $A$. racemosus $(30 \mu \mathrm{g} / \mathrm{ml})$ in the presence of 3 or $11 \mathrm{mM}$ glucose. Mann-Whitney $U$-test was used to evaluate statistical significance. ${ }^{*} P<0 \cdot 05,{ }^{+} P<0 \cdot 01$ compared with control (3 mM glucose with no extract). 

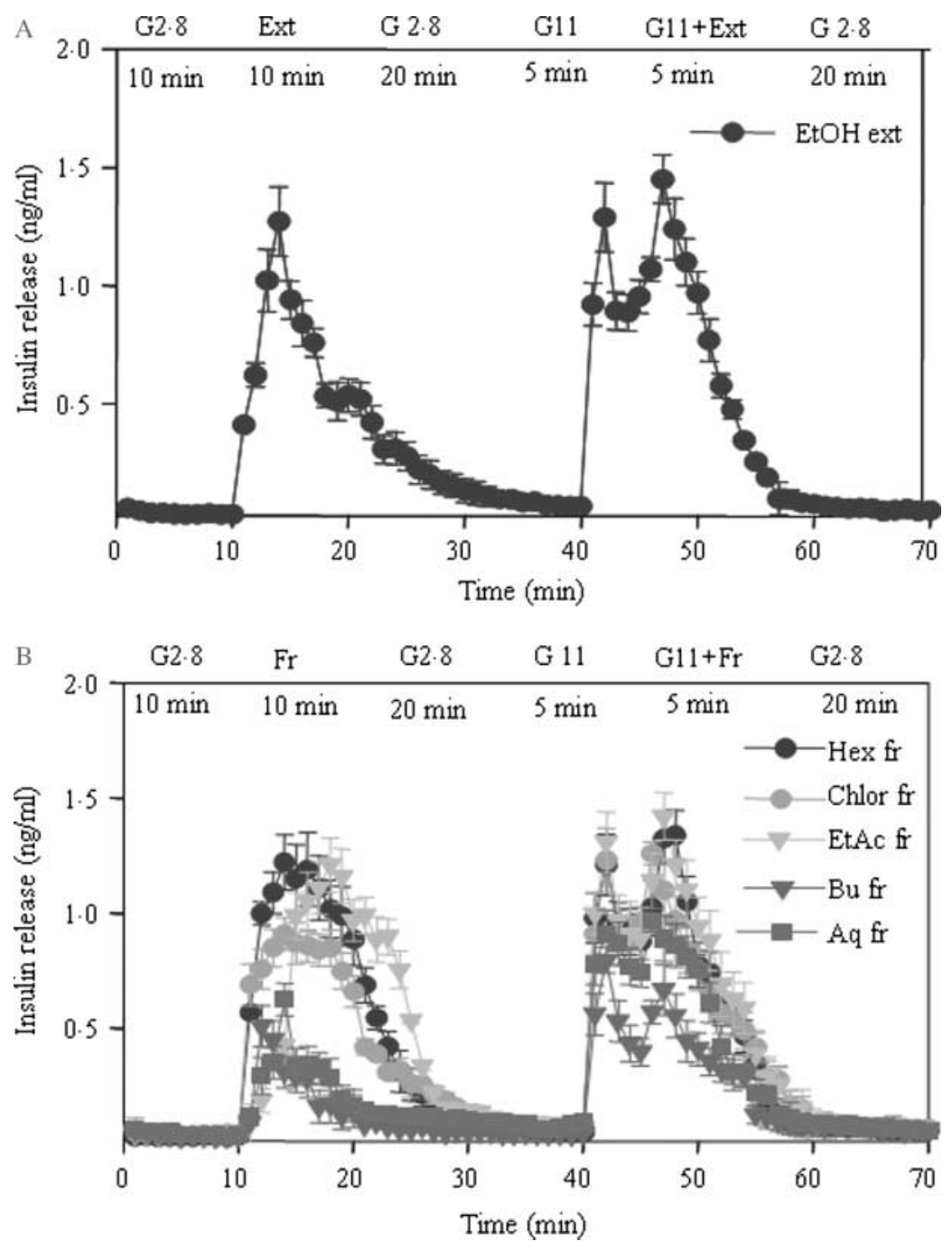

Figure 2 Effects of (A) ethanol extract and (B) five fractions of Asparagus racemosus on insulin release from perfused rat pancreas. Each point is the mean \pm s.D. of four to five separate experiments. Pancreas was perfused $(1 \mathrm{ml} / \mathrm{min})$ with the extract/fraction at a dose of $1 \mathrm{mg} / \mathrm{min}$. The glucose concentrations in the perfusate were raised from $2 \cdot 8$ to $11 \cdot 1 \mathrm{mM}$. Abbreviations: Ext, extract; G, glucose; fr, fraction; Hex, hexane; Chlor, chloroform; EtAc, ethyl acetate; $\mathrm{Bu}$, butanol; $\mathrm{Aq}$, aqueous.

Table 2 Effects of ethanol extract and partition fractions of $A$. racemosus on insulin release from perfused pancreas (peak value). Values are mean \pm s.D. $(n=4-6)$

Highest peak of insulin secretion $(\mathrm{ng} / \mathrm{ml})$

\begin{tabular}{|c|c|c|c|}
\hline Basal $2 \cdot 8 \mathrm{mM}$ glucose & $\begin{array}{c}2 \cdot 8 \mathrm{mM} \text { glucose }+ \\
\text { extract/fraction }\end{array}$ & $11 \mathrm{mM}$ glucose & $\begin{array}{l}11 \mathrm{mM} \text { glucose }+ \\
\text { extract/fractions }\end{array}$ \\
\hline $0 \cdot 06 \pm 0 \cdot 005$ & $1 \cdot 27 \pm 0 \cdot 09^{+}$ & $1 \cdot 29 \pm 0 \cdot 13$ & $1 \cdot 45 \pm 0 \cdot 10^{\ddagger}$ \\
\hline $0 \cdot 05 \pm 0 \cdot 004$ & $0 \cdot 62 \pm 0.08^{+}$ & $0.91 \pm 0.09$ & $0 \cdot 99 \pm 0 \cdot 79$ \\
\hline $0.06 \pm 0.009$ & $0.18 \pm 0.09 *$ & $0.79 \pm 0.08$ & $0.66 \pm 0.09$ \\
\hline $0 \cdot 04 \pm 0.008$ & $1 \cdot 16 \pm 0.12^{+}$ & $1 \cdot 31 \pm 0.11$ & $1 \cdot 42 \pm 0 \cdot 13^{\ddagger}$ \\
\hline $0 \cdot 05 \pm 0.006$ & $0.91 \pm 0.08^{\dagger}$ & $1 \cdot 21 \pm 0 \cdot 10$ & $1 \cdot 31 \pm 0 \cdot 12^{\ddagger}$ \\
\hline $0 \cdot 03 \pm 0 \cdot 004$ & $1 \cdot 22 \pm 0 \cdot 15^{\dagger}$ & $1 \cdot 22 \pm 0.95$ & $1 \cdot 34 \pm 0 \cdot 11^{\neq}$ \\
\hline
\end{tabular}

\section{Group}

Ethanol extract

Aqueous fraction

Butanol fraction

Ethylacetate fraction

Chloroform fraction

Hexane fraction
$1 \cdot 27 \pm 0.09^{\dagger}$
$0 \cdot 62 \pm 0.08^{\dagger}$
$0 \cdot 18 \pm 0.09^{*}$
$1 \cdot 16 \pm 0 \cdot 12^{\dagger}$
$0.91 \pm 0.08^{\dagger}$
$1 \cdot 22 \pm 0 \cdot 15^{\dagger}$

$0 \cdot 91+0 \cdot 09$

$\pm 0 \cdot 08$

$1 \cdot 21 \pm 0 \cdot 10$

$1 \cdot 34 \pm 0 \cdot 11^{\ddagger}$

${ }^{*} P<0 \cdot 01,{ }^{\dagger} P<0 \cdot 001$ compared with $2 \cdot 8 \mathrm{mM}$ glucose. ${ }^{\ddagger} P<0 \cdot 05$ compared with $11 \mathrm{mM}$ glucose. 
$1 \cdot 2 \pm 0 \cdot 1 \mathrm{ng} / \mathrm{ml})$. These fractions stimulated further insulin secretion at $11 \cdot 1 \mathrm{mM}$ glucose (peak output, $1 \cdot 2 \pm 0 \cdot 9$ vs $1 \cdot 3 \pm$ $0 \cdot 1 \mathrm{ng} / \mathrm{ml}, 1 \cdot 3 \pm 0 \cdot 1$ and $1 \cdot 4 \pm 0 \cdot 1 \mathrm{ng} / \mathrm{ml}$ respectively; $P<$ $0 \cdot 05)$. Aqueous and butanol fractions showed less prominent effects on insulin release, especially at the lower glucose concentration $0 \cdot 05 \pm 0 \cdot 004 \mathrm{ng} / \mathrm{ml}(2 \cdot 8 \mathrm{mM}$ glucose (basal)) vs $0.91 \pm 0.09 \mathrm{ng} / \mathrm{ml}$ (aqueous extract) and $0.06 \pm 0.01 \mathrm{ng} / \mathrm{ml}$ (basal) vs $0.79 \pm 0.08 \mathrm{ng} / \mathrm{ml}$ (butanol extract respectively; Fig. 2B and Table 2).
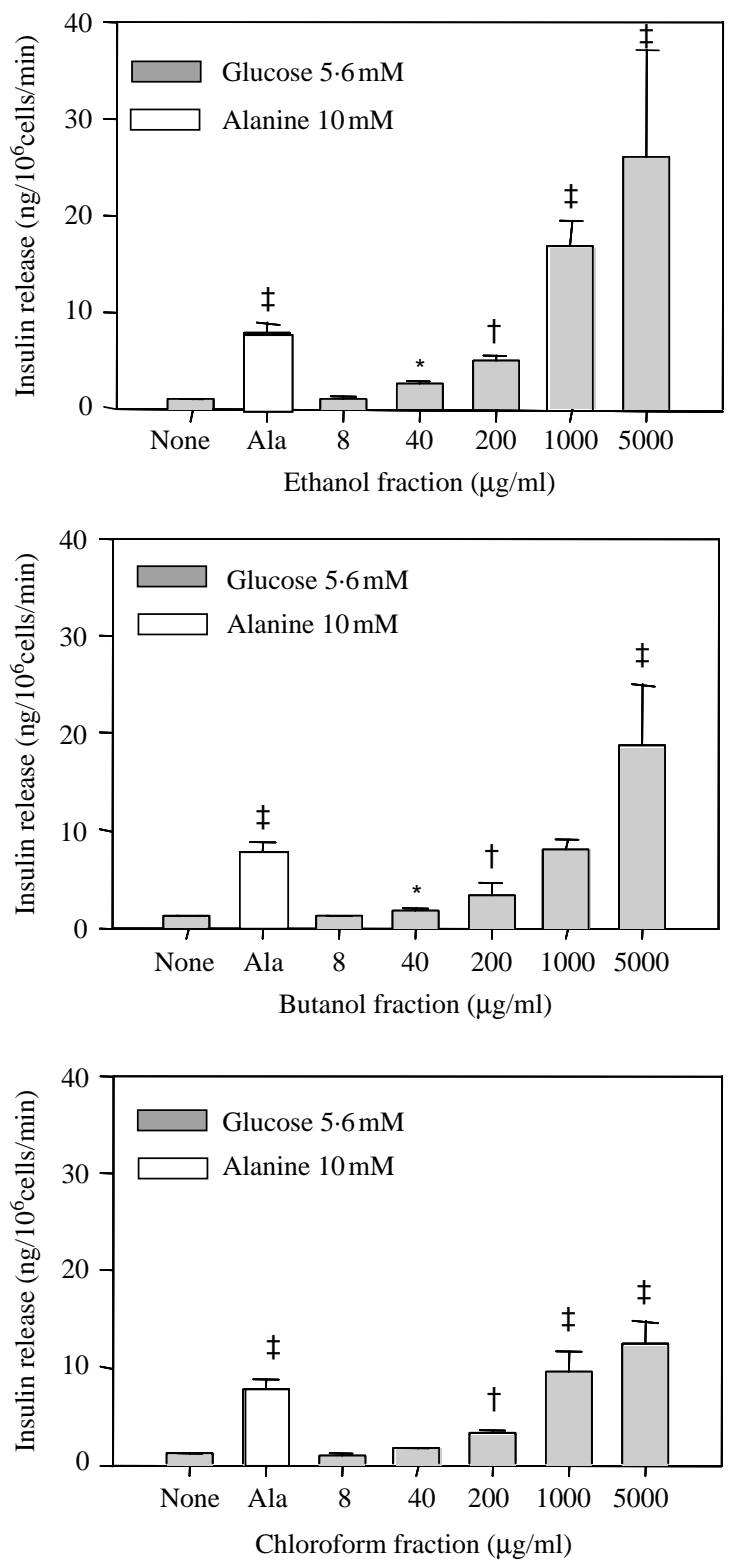

Effects of A. racemosus on insulin secretion from isolated islets

Ethanol extract and four partition fractions (ethyl acetate, butanol, chloroform and hexane) induced a significant increase in insulin secretion from isolated rat islets compared with $3 \mathrm{mM}$ glucose $(P<0 \cdot 01,<0 \cdot 01$, and $<0 \cdot 05$ respectively; Table 1). Increasing glucose concentrations from 3 to $11 \cdot 1 \mathrm{mM}$ caused a two-fold increase in insulin release. The effects of stimulatory plant extract/fractions were also
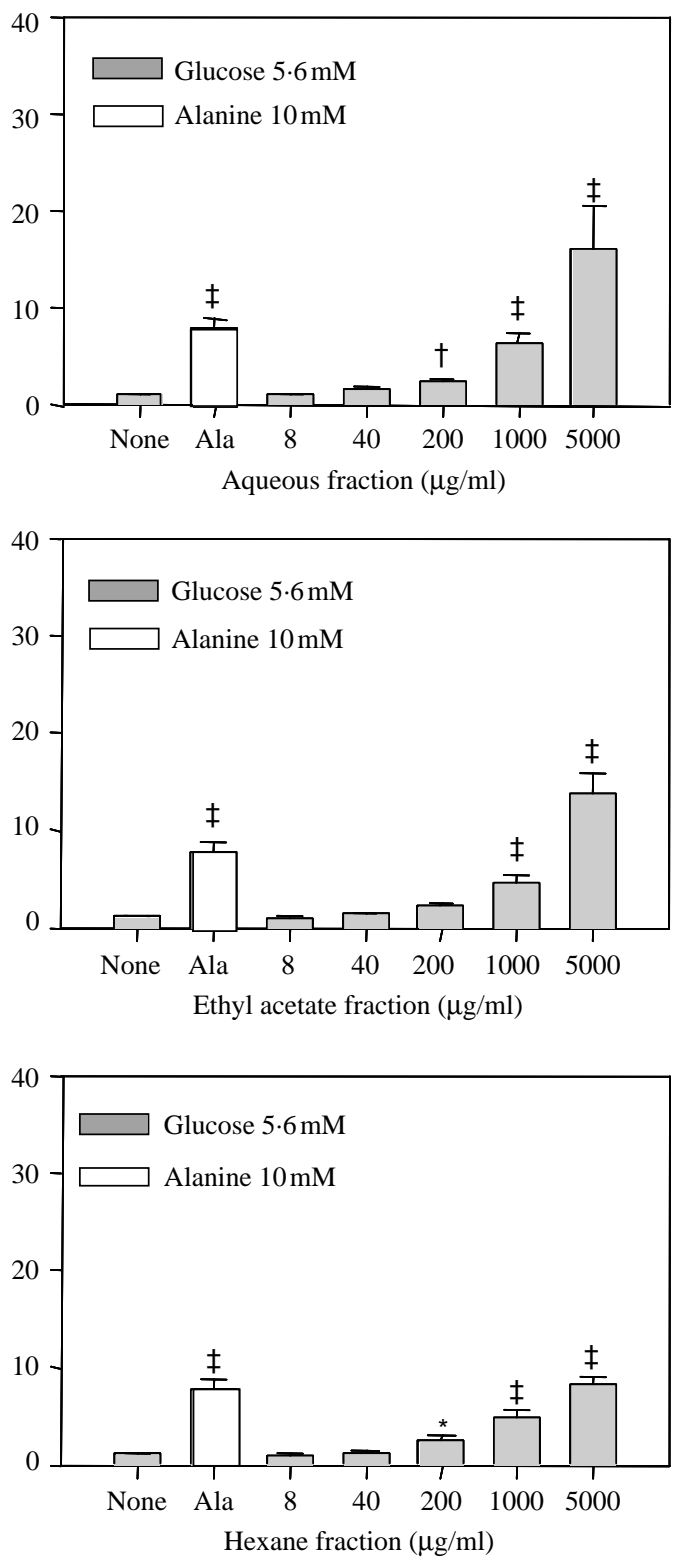

Figure 3 Acute effects of different concentrations of ethanol extract and five partition fractions of Asparagus racemosus on insulin release from BRIN-BD11 cells. Results are the mean \pm s.D. of eight separate observations. ${ }^{*} P<0 \cdot 05,{ }^{\dagger} P<0 \cdot 01$, ${ }^{\ddagger} P<0.001$ compared with $5.6 \mathrm{mM}$ glucose. One-way ANOVA was performed and pairwise comparisons to the control $(5 \cdot 6 \mathrm{mM}$ glucose) group used Dunnett's test to preserve an overall error rate of $5 \%$. Ala, alanine. 

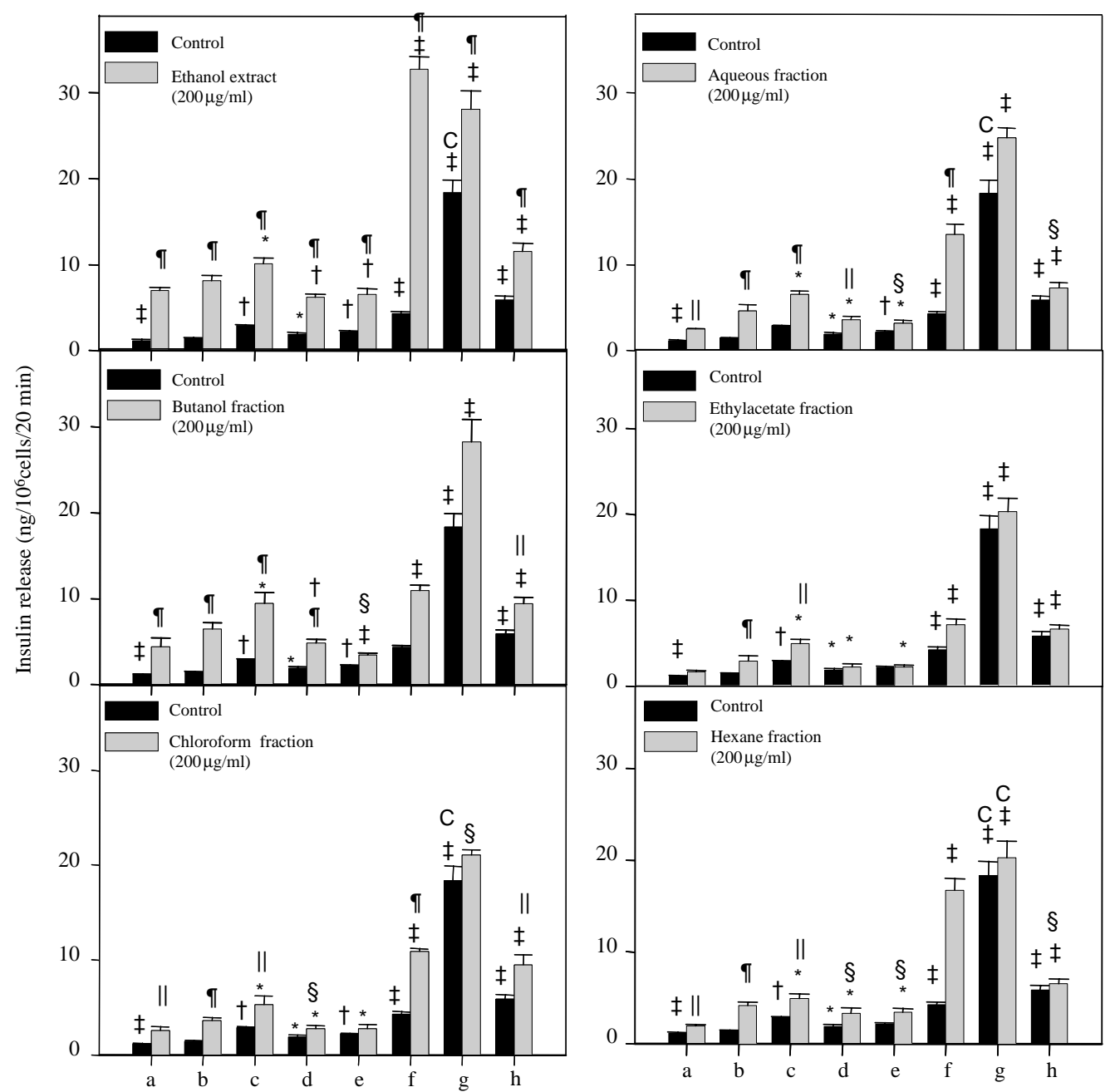

Figure 4 Effects of ethanol extract and five partition fractions of $A$. racemosus on insulin release from BRIN-BD11 cells in the presence of established stimulants and inhibitors of insulin secretion. Results are the mean \pm s.D. of eight separate observations. ${ }^{*} P<0 \cdot 05,{ }^{\dagger} P<0 \cdot 01,{ }^{\ddagger} P<0 \cdot 001$ compared with respective $5 \cdot 6 \mathrm{mM}$ glucose (control) in the presence or absence of plant extract. ${ }^{\S} P<0 \cdot 05, " 1 P<0 \cdot 01,{ }^{\Uparrow} P<0.001$ compared with the respective incubations in the absence of plant extract. ${ }^{\mathrm{a}} P<0 \cdot 05,{ }^{\mathrm{b}} P<0 \cdot 01,{ }^{\mathrm{c}} P<0 \cdot 001$ compared with respective $16.7 \mathrm{mM}$ glucose (controls) in the presence or absence of plant extract. One-way ANOVA was performed and pairwise comparisons to the control group (5.6 mM glucose) performed using Dunnett's test to preserve an overall error rate of $5 \%$. Letter codes: a, 0 mM glucose; b, $5.6 \mathrm{mM}$ glucose; c, 5.6 mM glucose $+50 \mu \mathrm{M}$ verapamil; d, $16.7 \mathrm{mM}$ glucose; e, 5.6 mM glucose $+300 \mu \mathrm{M}$ diazoxide; f, 5.6 mM glucose $+100 \mu \mathrm{M} \mathrm{IBMX} ; \mathrm{g}, 16 \cdot 7 \mathrm{mM}$ glucose $+30 \mathrm{mM} \mathrm{KCl} ; \mathrm{h}, 5 \cdot 6 \mathrm{mM}$ glucose $+200 \mathrm{mM}$ tolbutamide.

enhanced. The aqueous fractions did not show any stimulatory effects on insulin release in these experiments.

\section{Effects of A. racemosus on insulin secretion from clonal BRIN-BD11 cell-line}

Figure 3 shows the effects of a range of concentrations of ethanol extract and five partition fractions (aqueous, butanol, ethyl acetate, chloroform and hexane) of $A$. racemosus on insulin secretion from BRIN-BD11 cells. Alanine $(10 \mathrm{mM})$ was used as a positive control in this set of experiments. Ethanol extract $(40-5000 \mu \mathrm{g} / \mathrm{ml})$ stimulated insulin release in a concentration-dependent manner compared with control (5.6 mM glucose). The higher concentrations (1000$5000 \mu \mathrm{g} / \mathrm{ml}$ ) were associated with a $20-30 \%$ reduction in cellular viability. Aqueous and chloroform fractions were equipotent at stimulating insulin secretion from $40 \mu \mathrm{g} / \mathrm{ml}$. However, enhanced insulin release was noted at concentrations of $200 \mu \mathrm{g} / \mathrm{ml}$ and above with butanol, ethyl acetate and hexane fractions $(P<0 \cdot 05-0 \cdot 001)$. Concentrations of all five fractions between 40 and $200 \mu \mathrm{g} / \mathrm{ml}$ did not affect the cells viability (data not shown).

Further studies using non-toxic concentrations evaluated possible mechanisms underlying the actions of $A$. racemosus. 


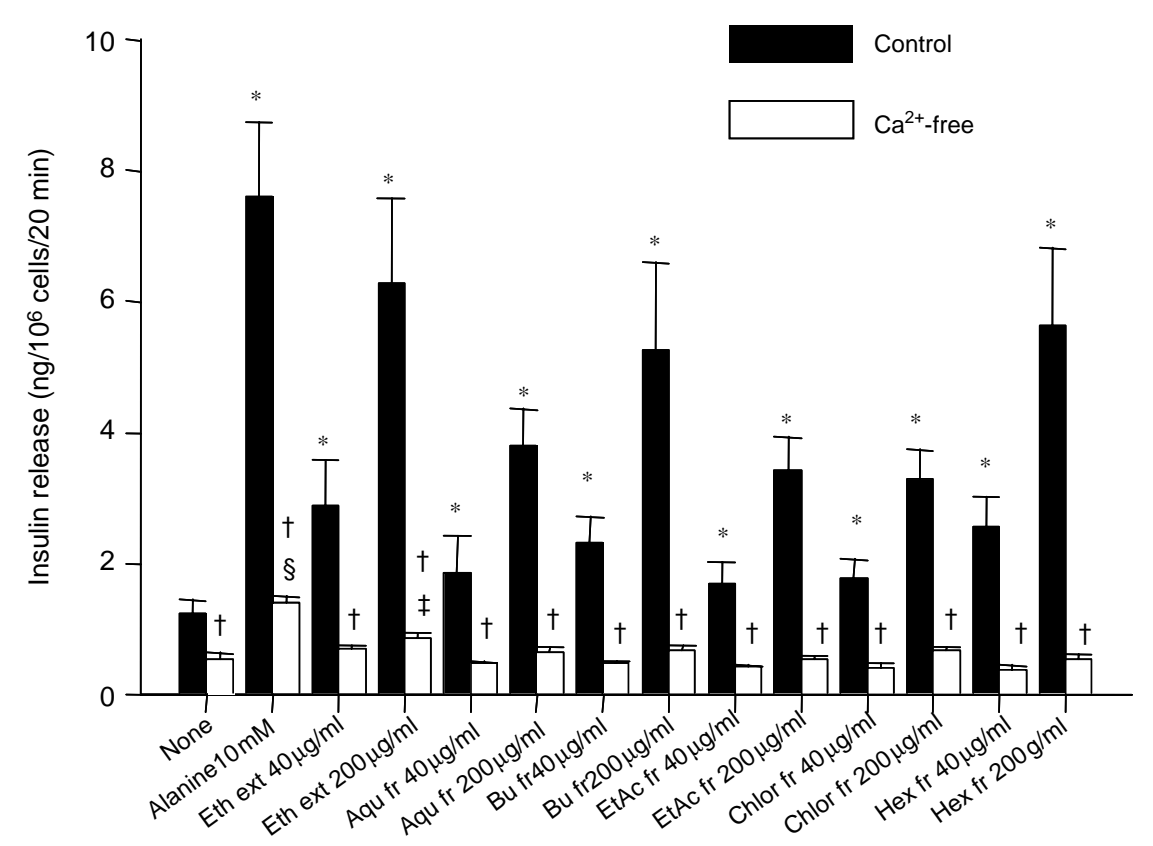

Figure 5 Effects of various concentrations of the ethanol extract and partition fractions of $A$. racemosus on insulin release from BRIN-BD11 cells in the presence and the absence of $\mathrm{Ca}^{2+}$. Results are mean \pm s.D. of eight separate observations. $* P<0 \cdot 001$ compared with $5 \cdot 6 \mathrm{mM}$ glucose in the presence of $\mathrm{Ca}^{2+} .{ }^{+} P<0 \cdot 001$ compared with the respective concentration in the presence of $\mathrm{Ca}^{2+}{ }^{\ddagger} P<0 \cdot 05,{ }^{\S} P<0 \cdot 001$ compared with $5 \cdot 6 \mathrm{mM}$ glucose in the absence of $\mathrm{Ca}^{2+}$. One-way ANOVA was performed and pairwise comparisons to the control ( $5.6 \mathrm{mM}$ glucose) group performed using Dunnett's test to preserve an overall error rate of $5 \%$. Abbreviations: Eth ext, ethanol extract; Aqu fr, aqueous fraction; Bu fr, butanol fraction; EthAc fr, ethyl acetate fraction; Chlor fr, chloroform fraction; Hex fr, hexane fraction.

As shown in Fig. 4, ethanol extract of A. racemosus (200 $\mu \mathrm{g} /$ $\mathrm{ml}$ ) exhibited a ninefold increase in insulin release $(P<0 \cdot 001)$. This effect was significantly enhanced in the presence of $16 \cdot 7 \mathrm{mM}$ glucose $(P<0 \cdot 05)$, IBMX $(P<0 \cdot 001)$ and tolbutamide $(P<0 \cdot 001)$. Modest inhibitory effects were observed in the presence of diazoxide $(P<0 \cdot 01)$ and verapamil $(P<0 \cdot 01)$. The ethanol extract also maintained its ability to increase insulin secretion in cells depolarized with $30 \mathrm{mM} \mathrm{KCl}$ (Fig. 3). Similar effects were noted for aqueous, butanol, ethyl acetate, chloroform and hexane fractions in the presence of insulin secretagogues (glucose, IBMX, tolbutamide), inhibitors (diazoxide and verapamil) and depolarizing concentrations of $\mathrm{KCl}$. As shown in Fig. 5, omission of $\mathrm{Ca}^{2+}$ from incubation buffer significantly reduced $(P<0 \cdot 001)$ the insulin-releasing ability of the extract and abolished that of the all partition fractions $(P<0 \cdot 001)$.

Effects of A. racemosus on intracellular calcium in clonal BRINBD11 cell line

Figure 6 shows the effects of the ethanol extract and five partition fractions (aqueous, butanol, ethyl acetate, chloroform and hexane) on intracellular $\mathrm{Ca}^{2+}\left(\left[\mathrm{Ca}^{2+}\right]_{\mathrm{i}}\right)$. A sharp increase in $\left(\left[\mathrm{Ca}^{2+}\right]_{\mathrm{i}}\right)$ was observed compared with $5.6 \mathrm{mM}$ glucose alone. The magnitude of the effect was somewhat less with the aqueous and ethyl acetate fractions.

\section{Discussion}

Presently available drug regimens for the management of diabetes mellitus have certain drawbacks and are not readily available in developing parts of the world (Yudkin 2000, Yach et al. 2004). There is a need for a move widely applicable, safer and more effective anti-diabetic drug therapy. In this study, the insulinotropic effects of ethanol extract and five partition fractions (aqueous, butanol, ethyl acetate, chloroform and hexane) of $A$. racemosus were assessed using perfused rat pancreas, isolated rat islets and a clonal rat insulin secreting cell line.

The ethanol extract and three fractions (ethyl acetate, butanol and aqueous) were found to be highly effective in stimulating insulin secretion from the perfused pancreas. This effect was immediate and enhanced further into a biphasic profile at $11.1 \mathrm{mM}$ glucose. Thus, the profile of insulin release from perfused pancreas suggests that the actions of ethanol extract and other fractions might not be limited to first-phase insulin secretion only. Similar effects were 

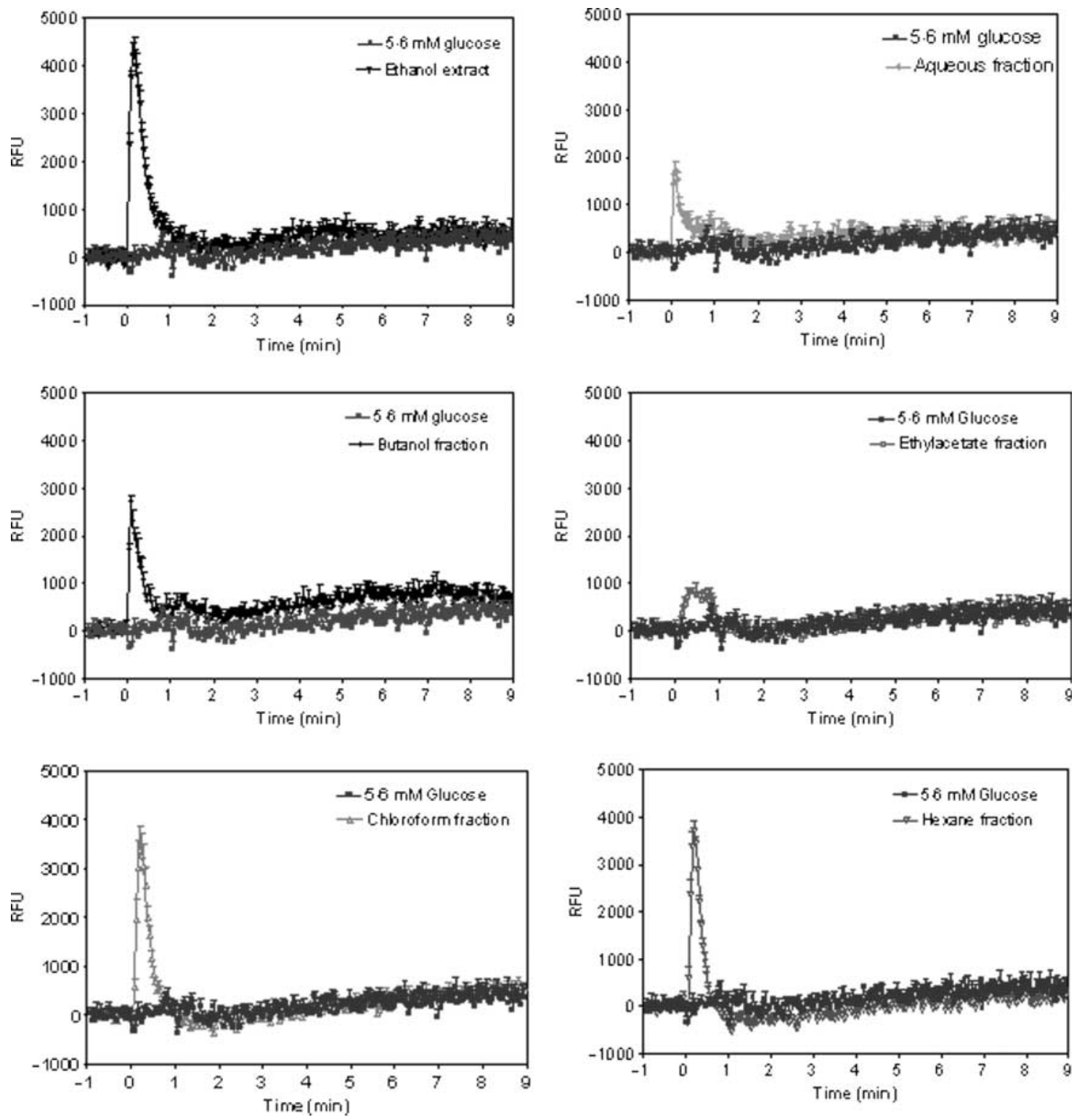

Figure 6 Effects of ethanol extract and five partition fractions of $A$. racemosus on intracellular $\mathrm{Ca}^{2+}$ influx in BRIN-BD11 cells. Each data point represents the mean \pm S.D. for six separate observations. RFU, relative fluorescent unit.

observed in acute studies of insulin release with isolated rat islets. Aqueous fraction had lesser effects and these results suggest that non-polar fractions of $A$. racemosus were more effective in enhancing insulin secretion. Insulinotropic effects of the extract/fractions were also evaluated in BRIN-BD11 cells. Using this cell line, the ethanol extract and each of the five fractions showed stepwise concentration-dependent stimulatory effects on insulin secretion at basal glucose concentration. A clear division was observed between insulin secretion and possible detrimental effects on cell viability. It is noteworthy that small differences in secretory responses were observed with the various $\beta$-cell models. However, this is unsurprising given differences in origin of $\beta$-cells, mode of presentation of extract/fraction constituents, heterogeneity and likely concentration dependency.

Further studies to examine the mechanism underlying the actions of $A$. racemosus extracts and fractions indicated that the insulin-releasing machinery of the $\beta$-cells has been mediated through specific secretory pathways. For example, the $\mathrm{K}_{\text {ATP }}$ channel opener, diazoxide (Henquin et al. 1992) reduced the insulin-releasing action indicating that part of $A$. racemosus action involves on inhibitory effect on $\mathrm{K}_{\mathrm{ATP}}$ channels. The voltage-dependent calcium channel blocker, verapamil also significantly reduced insulin release providing evidence 
that $\mathrm{Ca}^{2+}$ plays a key role in mediating the effect. Consistent with this view, insulin secretory effects of the extract were abolished in the absence of extracellular $\mathrm{Ca}^{2+}$ and the extract provoked immediate elevation of $\left[\mathrm{Ca}^{2+}\right]_{\mathrm{I}}$ in BRIN-BD11 cells. The action of the extract was potentiated by $16.7 \mathrm{mM}$ glucose, suggesting that $\beta$-cell glucose metabolism is important for augmentation of insulinotropic effect. However, the extract induced insulin release in cells depolarized by $30 \mathrm{mM} \mathrm{KCl}$ or tolbutamide suggesting that depolarization is not the sole mechanism through which the extract exerts its effects. IBMX, an inhibitor of cyclic AMP phosphodiesterase, potentiated insulin release by increased levels of intracellular cAMP (Sharp 1979). Interestingly, effect of IBMX was enhanced by the presence of the extract, suggesting the possible involvement in cAMP production pathway.

The five partition fractions (aqueous, butanol, ethyl acetate chloroform and hexane) of $A$. racemosus showed similar effects on insulin secretion to the parent ethanol extract to glucose, IBMX, tolbutamide and depolarising conditions, diazoxide, verapamil, and $\mathrm{Ca}^{2+}$ depletion. Similarly, stimulatory effects on intracellular $\mathrm{Ca}^{2+}$ were observed with the fractions suggesting same or similar active molecules acting through common pathways.

In conclusion, this study has shown that $A$. racemosus extracts exerted significant stimulatory effects on insulin secretion mediated through physiological pathways. Such an action may clearly contribute to the observed anti-hyperglycaemic actions reputed in rats and rabbits (Rana et al. 1994). Future work directed towards the identification of active principle(s) from $A$. racemosus may provide the opportunity for the development of a novel class of agents for the treatment of diabetes.

\section{Acknowledgements}

The authors declare that there is no conflict of interest that would prejudice the impartiality of this scientific work.

\section{References}

Akhtar MS \& Shah MV 1993 Elemental constituents of antidiabetic screening of a folklore medicinal plant prescription. Indian Journal of Toxicology, Occupational and Environmental Health 246.

Atta-Ur-Rahman AU \& Zaman K 1989 Medicinal plants with hypoglycaemic activity. Journal of Ethnopharmacology 26 1-55.

Balansard S \& Rayband M 1987 Diuretic action of Asparagus racemosus. Critical Reviews in Society of Biology 126 954-956.

Booth GL, Kapral MK, Fung K \& Tu JV 2006 Relation between age and cardiovascular disease in men and women with diabetes compared with non-diabetic people: a population-based retrospective cohort study. Lancet 368 29-36.

Chadha YR 1985 The Wealth of India, vol 1, pp 468-472. New Delhi: Publication and Information Directorate.

Dalvi SS, Nadkarni PM \& Gupta KC 1990 Effect of A. racemosus (Shatavari) on gastric emptying time in normal healthy volunteers. Journal of Postgraduate Medicine 36 91-94.
De B, Maiti RN, Joshi VK, Agrawal VK \& Goel RK 1997 Effect of some Sitavirya drugs on gastric secretion and ulceration. Indian Journal of Experimental Biology 35 1084-1087.

Dhuley JN 1997 Effect of some Indian herbs on macrophage functions in ochratoxin A treated mice. Journal of Ethnopharmacology 58 15-20.

Edenharder R 1990 Antimutagenic activity of vegetable and fruit extracts against in vitro benzo(a)pyrene. Zeitschrift fur Gesamte Hygiene 36 144-148.

Flatt PR \& Bailey CJ 1981 Abnormal plasma glucose and insulin responses in heterozygous lean $(o b /+)$ mice. Diabetologia 20 573-577.

Gang ZZ, Li LZ \& Xian LX 1997 Study on the isolation, purification and antioxidation properties of polysaccharides from Spirulina maxima. Acta Botanica Sinica 39 77-81.

Giroux MH, Portha B, Kergoat M, Bailbe D \& Picon L 1983 Glucose insensitivity and amino-acid hypersensitivity of insulin release in rats with non-insulin-dependent diabetes: a study with the perfused pancreas. Diabetes 32 445-451.

Gray AM \& Flatt PR 1997 Nature's own pharmacy: the diabetes perspective. Proceedings of the Nutrition Society $\mathbf{5 6}$ 507-517.

Henquin JC, Debuyser A, Drews G \& Plant TD 1992 Regulation of $\mathrm{K}^{+}$ permeability and membrane potential in insulin-secretory cells. In Nutrient Regulation of Insulin Secretion, pp 173-192. Ed. PR Flatt. London: Porland.

Holman RR \& Turner RC 1991 Oral agents and insulin in the treatment of NIDDM. In Text Book of Diabetes Pickup, pp 67-469. Eds J Pickup \& G Williams. Oxford: Blackwell.

Hunt SM, Chrznowska C, Barnett CR, Brand HN \& Fawell JK 1987 A comparison of in vitro cytotoxicity assays and their application to water samples. Alternatives to Laboratory Animals 15 20-29.

Ivorra MD, Paya M \& Villar A 1989 A review of natural products and plants as potent antidiabetic drugs. Journal of Ethnopharmacology 27 243-276.

Kamat JP, Boloor KK, Devasagayam TPA \& Venkatachala SR 2000 Antioxidant properties of Asparagus racemosus against damage induced by gamma-radiation in rat liver mitochondria. Journal of Ethnopharmacology 71 425-435.

Kameswara Rao B, Giri R, Kesavulu MM \& Apparao CH 1997 Herbal medicine in the management of diabetes mellitus. Manphar Vaidhya Patrika 1 33-35.

Liu J, Yeo HC, Doniger SJ \& Ames BN 1997a Assay of aldehydes from lipid peroxidation: gas chromatography-mass spectrometry compared to thioabarbituric acid. Analytical Biochemistry 245 161-166.

Liu SX, Chen Y, Zhou M \& Wan J $1997 b$ Protective effect of the polysaccharide kreskin on inhibition of lipo-polysaccharide-induced nitric oxide production in macrophages caused by oxidized low-density lipoprotein. Medical Science Research 25 507-509.

McClenaghan NH, Barnett CR, Ah-Sing E, Abdel-Wahab YHA, O'Harte FPM, Yoon T-W, Swanston-Flatt SK \& Flatt PR 1996 Characterization of a novel glucose-responsive insulin-secreting cell line, BRIN-BD11, produced by electrofusion. Diabetes 45 1132-1140.

Miguel JC, Patterson S, Abdel-Wahab YHA, Mathias PC \& Flatt PR 2004 Time-correlation between membrane depolarization and intracellular calcium in insulin secretion BRIN-BD11cells: studies using FLIPR. Cell Calcium 36 43-50.

Moskalewski 1969 Studies on the culture and transplantation of Isolated islets of Langerhans of the guinea pig. Proceedings of the Koninklijke Nederlandse Akademie van Wetenschappen. Series C. Biological and Medical Sciences 72 157-171.

Mukherjee SK 1981 Indigenous drugs in Diabetes mellitus. Journal of the Diabetic Association of India XXI 97-106.

Nadkarni AK 1976 India Materia Medica, pp 151-155. Bombay: Popular Prakashan

Nwafor PA, Okwuasaba FK \& Binda LG 2000 Antidiarrhoeal and antiulcerogenic effects of methanolic extract of Asparagus pubescens root in rats. Journal of Ethnopharmacology 72 421-427.

Oliver-Bever B 1986 Oral hypoglycaemic action. Medicinal Plants in Tropical West Africa., London: Cambridge University Press.

Prout TE 1974 Excerpta Medica. In Proceedings VIII Congress of International Diabetes Federation, p 162Eds WJ Malaisse \& J Pirart. Amsterdam: Elsevier Publishing.

Rai MK 1995 A review on some antidiabetic plants of India. Ancient Science of Life 14 42-54. 
Rana TS, Singh KK \& Rao RR 1994 Some interesting reports on indigenous herbal remedies for diabetes mellitus from India. Fourth Int Cong Ethnobiol, NBRI, Lukhnow 47 17-21.

Rege NN, Thatte UM \& Dahanukar SA 1999 Adaptogenic properties of six rasayana herbs used in Ayurvedic medicine. Phytotherapy Research 3 275-291.

Roglic G, Unwin N, Bennett PH, Mathers C, Tuomilohto J, Nag S, Connolly V \& King H 2005 The burden of mortality attributable to diabetes: realistic estimate for the year 2000. Diabetes Care 28 2130-2135.

Sairam K, Priyambada S, Aryya NC \& Goel RK 2003 Gastroduodenal ulcer protective activity of $A$. racemosus: an experimental, biochemical and histological study. Journal of Ethnopharmacology 86 1-10.

Shao Y, Chin C-K, Ho C-T, Ma W, Garrison SA \& Huang MT 1996 Antitumour activity of the crude saponins obtained from asparagus. Cancer Letters 104 31-36.

Sharma S, Ramji S, Kumari S \& Bapna JS 1996 Randomized control trial of A. racemosus (Shatavari) as a lactogogue in lational inadequacy. Indian Pediatrics 32 675-677.

Sharp GWG 1979 The adenylate cyclase-cyclic AMP system in islets of Langerhans and its role in the control of insulin release. Diabetologia 16 287-297.

Shimoyamada M, Suzuki M, Sonta H, Maruyama M \& Okubo K 1990 Antifungal activity of the saponin fraction obtained from asparagus and its active principle. Agricultural and Biological Chemistry 54 2553-2557.

Swanston-Flatt SK, Day C, Flatt PR \& Bailey CJ 1991a In Evaluation of the antihyperglycaemic properties of traditional plant treatments for diabetes, vol 3, pp 286-293. Ed. E Shafrir. London: Smith-Gordon and Company Ltd.

Swanston-Flatt SK, Flatt PR, Day C \& Bailey CJ $1991 b$ Traditional dietary adjuncts for the treatment of diabetes mellitus. Proceedings of the Nutrition Society $\mathbf{5 0}$ 641-651.

Thatte UM \& Dahanukar SA 1988 Comparative study of immunomodulating activity of Indian medicinal plants, lithium carbonate and glucan. Methods and Findings in Experimental and Clinical Pharmacology 10 639-644.

Yach D, Hawkes C, Gould CL \& Hofman KL 2004 The global burden of chronic diseases: overcoming impediments to prevention and control. Journal of the American Medical Association 291 2616-2622.

Yudkin JS 2000 Insulin for the world's poorest countries. Lancet 355 919-921.

Zeng N, Meng X \& Zhang Y 1997 Studies on the antioxidative effect of constituents of Herba epimedii (ESPS). Zhongguo Zhongyao Zazhi 22 46-48.

\section{Received 26 July 2006 \\ Accepted 10 October 2006}

